\title{
Sorghum stover as ruminant food in Ethiopia: effect of cultivar, site of growth, pre-harvest leaf stripping and storage on yield and morphology
}

\author{
E. L. K. Osafo', E. Owen' ${ }^{2}$, A. N. Said', M. Gill ${ }^{3}$, A. B. McAllan ${ }^{4}$ and Y. Kebede \\ IInternational Livestock Centre for Africa, PO Box 5689, Addis Ababa, Ethiopia \\ ${ }^{2}$ Department of Agriculture, Reading University, Reading RG6 2AT \\ ${ }^{3}$ Natural Resources Institute, Chatham Maritime, Kent ME4 4TB \\ ${ }^{4} A F R C$ Institute of Grassland and Environmental Research, Hurley, Maidenhead SL6 5LR \\ ${ }^{5}$ Institute of Agricultural Research, Melkassa, Ethiopia
}

\section{Introduction}

The development of bird-resistant varieties (BR) of sorghum has resulted in varieties which could have different yields and botanical composition of stover compared with non bird-resistant (non-BR) ones. Farmers in Ethiopia practise leaf stripping before harvest to provide additional food for livestock. Choice of sorghum variety therefore depends not only on grain yield but also on the feeding value of

Table 1 Effect of site and cultivar on yield of stover and proportion of leaf plus sheath in stovert

\begin{tabular}{|c|c|c|c|c|}
\hline \multirow[b]{2}{*}{ Cultivar } & \multicolumn{2}{|c|}{ Debre Zeit } & \multicolumn{2}{|c|}{ Melkassa } \\
\hline & $\begin{array}{l}\text { tDM } \\
\text { per } \\
\text { ha }\end{array}$ & $\begin{array}{c}\text { Leaf + } \\
\text { sheath } \\
\text { proportion }\end{array}$ & $\begin{array}{l}\text { tDM } \\
\text { per } \\
\text { ha }\end{array}$ & $\begin{array}{c}\text { Leaf }+ \\
\text { sheath } \\
\text { proportion }\end{array}$ \\
\hline \multicolumn{5}{|l|}{ Bird-resistant } \\
\hline $\begin{array}{l}\text { Aligider wodi } \\
\text { ferega }\end{array}$ & 2.87 & 0.327 & $4 \cdot 21$ & 0.254 \\
\hline Framida & $4 \cdot 17$ & 0.341 & $4 \cdot 28$ & 0.335 \\
\hline Ikinyaruka & $7 \cdot 28$ & 0.315 & 4.07 & 0.352 \\
\hline MW5020 & 3.09 & 0.618 & 2.77 & 0.584 \\
\hline Ruffe & 5.03 & 0.388 & $8 \cdot 77$ & 0.364 \\
\hline Seredo & 2.97 & 0.466 & 3.28 & 0.388 \\
\hline Serena & 3.55 & 0.506 & 4.03 & 0.486 \\
\hline X3524 & 3.59 & 0.394 & 3.07 & 0.425 \\
\hline \multicolumn{5}{|l|}{ Non-bird-resistant } \\
\hline ACC69391 & 3.83 & 0.316 & $7 \cdot 32$ & 0.355 \\
\hline ACC69447 & 4.00 & 0.311 & 2.83 & 0.321 \\
\hline Dinkamash & 2.46 & 0.347 & 1.75 & 0.342 \\
\hline Gambella & 2.69 & 0.311 & $4 \cdot 28$ & 0.428 \\
\hline $\begin{array}{l}\text { PGRCE222880 } \\
(\text { SC } 423 \times \text { CS3541 }\end{array}$ & $2 \cdot 81$ & 0.305 & 2.29 & 0.296 \\
\hline$\times$ E35-1)-2-1 & 1.87 & 0.448 & 0.83 & 0.400 \\
\hline
\end{tabular}

t s.e.d. for comparing any pair of means of stover yield $=1.48$. Coefficient of variation (based on residual s.d.) of stover yield $=0.488$. the stover produced. Stovers are fed for up to 6 months after harvest; little is known about changes in nutritive value (e.g. leaf loss) during this period.

The experiment undertaken therefore investigated effect of cultivar and site of growing sorghum upon yield and composition of stover. The effects of preharvest leaf stripping and post-harvest storage were also studied.

\section{Material and methods}

Fourteen varieties of sorghum were grown in 1990 at two sites (Debre Zeit: $1700 \mathrm{~m}$ and 700 to $900 \mathrm{~mm}$ rainfall; Melkassa: $1500 \mathrm{~m}$ and 500 to $800 \mathrm{~mm}$ rainfall) using three replicate plots per cultivar and site. At harvest, grain and stover yields were recorded and the stover fractionated into leaf, sheath and stem. A subplot investigated the effects upon grain and stover yields of four leaf stripping regimes viz. (1) no stripping; (2) five lower leaves removed at $50 \%$ flowering stage; (3) five lower leaves removed at the black layer stage; and (4) three lower leaves removed at $50 \%$ flowering and two removed at the black layer stage. At the Debre Zeit site, another subplot investigated the changes in botanical fractions of stover during field storage and barn storage, after harvesting.

\section{Results}

Yields of stover (Table 1) were highly variable but there were significant effects of cultivar $(P<0.0001)$ but not of site $(P>0.05)$. However, for grain yields there were significant effects of site $(P=0.005)$, cultivar $(P=0.0001)$ and site $X$ cultivar $(P=0.023)$. Proportions of leaf plus sheath in stovers were also highly variable (Table 1 ). 
Table 2 Effect of l'af stripping on, grain yicld (t dry matter per ha)t Mean (across variety)

Treatment

Debre Zeit Melkassa

1. No stripping

1.28

2. Five lower leaves at $50 \%$ flowering $\quad 1.34$

$1 \cdot 61$

3. Five lower leaves at black layer

$1 \cdot 25$

1.44

1.50

4. Three lower leaves at $50 \%$ flowering and two lower leaves at black layer $\quad 1.19$

1.56

+ s.e.d. for comparing any pair of means $=0 \cdot 08$. Coefficient of variation (based on residual s.d.) $=\mathbf{0 . 2 5 3}$.
Grain yields were not significantly affected by leaf stripping (Table 2) but there was much variation. Storage of stover caused loss of leaf and sheath.

\section{Conclusions}

Yield and composition of sorghum stovers were highly variable but nevertheless significantly affected by cultivar. Pre-harvest leaf stripping did not affect grain yield. Post-harvest storage of stover was associated with loss of leaf. There is a need for further research to develop management strategies for using sorghum stover as food. 